\title{
The impact of foreign direct investment on exports in Jordan: An empirical analysis
}

\author{
Shahriyar Mukhtarov \\ Department of World Economy, Baku Engineering University \\ UNEC Empirical Research Center, Azerbaijan State University of \\ Economics (UNEC), \\ Azerbaijan \\ smuxtarov@beu.edu.az
}

\section{Mustafa Mohammad Alalawneh}

School of Economics and Management, Khazar University

Azerbaijan

falconengineer81@yahoo.com

\section{Elsevar Ibadov}

Department of Accounting and Audit, Baku Engineering University

School of Business, Azerbaijan State University of Economics

(UNEC)

Azrerbaijan

eibadov@beu.edu.az.

\section{Ayten Huseynli}

Department of Economics and Management, Azerbaijan State

University of Economics (UNEC)

Azerbaijan

a.buseynli@unec.edu.az.

Abstract. This study investigates the impact of foreign direct investment (FDI) on exports in the case of Jordan, employing Autoregressive Distributed Lag Bounds Testing (ARDL BT) cointegration approach to the data ranging from 1980 to 2018. The results indicate that there is a long-run relationship among the variables. Also, we find that there is a positive and statistically significant impact of FDI on export in the long-run. The estimation results indicate that a $1 \%$ increase in FDI increases exports by $0.13 \%$.

Received: December, 2018 1st Revision: February, 2019 Accepted: July, 2019

DOI:

$10.14254 / 2071$ $8330.2019 / 12-3 / 4$

Keywords: foreign direct investment, exports, ARDL, Jordan.

JEL Classification: E20, E22, F10, F21 


\section{INTRODUCTION}

Foreign direct investment is seen as a major source of getting the required funds for investments hence most developing countries offer incentives to encourage FDI (United Nations, 2005). According to the report issued by the United Nations Conference on Trade and Development (UNCTAD), FDI flows have achieved growth rates higher than the growth rates in foreign trade and GDP globally (UNCTAD, 2005).

With foreign direct investment companies can expand their production operations because they have larger capital and the ability to borrow from international markets, thus benefiting from economies of scale, leading to an increase in exports of a host country.

In addition, local companies in host countries benefit from the trade information available to foreign direct investment companies from international industrial and commercial organizations. This also motivates local companies and drives them to improve their production, which is reflected in the increase of exports. This is the indirect effect (Jaumatte, 2004). Policymakers, especially those in developing countries, have come to the conclusion that foreign direct investment is needed to boost economic growth. It is claimed that FDI can create new employment opportunities, increase technological development in a host country and improve the economic condition of the country in general.

Economic openness to the outside world in all its dimensions is one of the main pillars of the general economic policy in Jordan. Openness of Jordanian economy with all its privileges would convey it from the previous stage which was depended on the protection and government support to the current stage based on economic liberalization, raising productivity and competitive advantage for the private sector. Successive governments of Jordan has worked to improve the investment climate through the process of updating and developing legislation in order to attract foreign capital where a number of agreements signed, at this, economic openness policy was one of the most important issues. Jordan has signed trade agreements with the United States and the European Union and the Arab states. It also joined the World Trade Organization in 2000 and signed the Establishment of Qualified Industrial Zone Jordanian Economic and Social Council, 2012).

Foreign direct investment growth has revived the debate about the impact of these investments on the host nation. With regard to benefits, many researchers discussed the importance of foreign investment for economic growth and the creation of an optimal economic environment with the deployment of technologies and transfer of expertise from developed countries so that to boost productivity and increase competitiveness in the sectors experiencing capital inflow (Dutt, 1998).On the other side, foreign investment creates unwanted traces in the economy by increasing the volume of imports which are often associated with production inputs of foreign direct investment. Therefore, possible disadvantages are trade deficit as well as deterioration of the balance of payments as a result of profits being transferred abroad (Todaro \& Smith, 2015).

This study aims to examine the impact of foreign direct investment on the exports during the period of 1980-2018 in Jordan. This is one of a few studies on the impact of FDI on the exports in Jordan and it uses a new methodology to achieve the goals. The economies of developing countries, including Jordan, often suffer from structural economic imbalances, especially in domestic investment spending and efficiency of investments, due to the lack of domestic financing and savings being either squandered abroad, or channeled on consumer leisure spending. Such a situation is often prompting these countries to move towards external financing and foreign direct investment in particular which is supposed to play an important active role in advancing economic development and enhancing productive capacities, technology transfer and rehabilitation of human capital. However, in some cases, FDI becomes a disincentive to economic growth as it is not accompanied by benefits from technological advances and instead, is focused on extractive industries, thus seeking to exploit the resources of a host country and minimize its 
improvement role. Therefore, this study will try to answer the question: Does FDI contribute to increasing exports in case of Jordan?

\section{LITERATURE REVIEW}

In this section, the similar studies devoted to the impact of FDI on the economy are reviewed. There are a vast of studies in economics literature investigating the impact of FDI on the economy. But several studies have been conducted to examine the impact of FDI on exports.

Some studies observed positive impacts and others got negative impacts, such as: Buckley et al., (2002) argue that the extent to which FDI contributes to growth depends on the economic and social conditions in the recipient country. They found that countries with high rate of savings, open trade system and high technical levels would more benefit from the increase of FDI to their economies. However, Duasa (2007) examined the causality between FDI and output growth the case of Malaysia. He found that there is no burly evidence of causal relationship between FDI and economic growth. A study by Zakia and Ziad (2007) had also examined the relationship between FDI and the economic expansion of Jordan, their results had shown that there is a significant relationship between FDI and productivity along with imports and output as well Abdul-razaq and Bataineh (2007) employ autoregressive integrated moving average (ARIMA) model, the model estimate the consequence of FDI inflows into Jordan over the period 2004- 2005.

The paper presented that foreign direct investment witnessed an increasing trend over the period 2004-2005. It estimated a positive impact of FDI inflows on macroeconomic variables. A study by Benmamoun and Lehnert (2013) also examined the impacts of FDI, worker remittances and Official development assistance (ODA) on the economic growth of developing countries by using panel data from 1990-2006. By applying system generalized method approaches, a positive and significant impact of FDI, the remittances and the Official development assistance (ODA) on the economic growth of the developing countries are reported. They also found that the contribution of the worker remittances to the economic growth is greater than FDI, and ODA.

The study of Olayiwolaand and Okodua (2013) examined the contribution of foreign direct investment to the performance of non-oil exports in Nigeria under the export-led growth hypothesis. The evidence confirmed that the bulk of the inflow of FDI into the country goes to the oil sector in the economy, the importance of the export-led growth hypothesis, and the dynamic interaction between FDI, non-oil exports and economic growth have been verified using variance analysis and response analysis; One-way causality extends from foreign direct investment to non-oil exports. The results also showed that the promotion of non-oil exports was essential for the effectiveness of FDI in Nigeria. And according to Mousawi study (2015) which aimed to investigate the factors influencing foreign direct investment (FDI) in Algeria during the period from 1996 to 2012. To achieve this objective, the VAR model was used in a reduced form for four variables (foreign direct investment, economic growth, exports, and real exchange rate). The results of the study showed no causal relationship between FDI and economic growth, a causal relationship between exports and FDI, as well as a causal link between FDI and the real exchange rate, which also showed that exports, had a positive impact on FDI while real exchange rate has a negative impact on foreign direct investment.

The study of Selim et al. (2016) examined and analyzed empirically the foreign direct investment and export performance during the period of 1996-2013 in Western Balkan countries. The paper also investigated for the fixed effects and individual heterogeneity across countries and years. Based on the panel regression techniques and least squares dummy variables (LSDV) regression method, FDI positively affect export performance in the sample countries in various model specifications. 
In addition, according to Sultanuzzman et al. (2018) which examined the long-run and short-run relationship between foreign direct investment (FDI) inflows, exports, and economic growth in Sri Lanka over the period of 1980-2016. The study implies Autoregressive Distributed Lag (ARDL) bounds testing approach to reveal the relationship between the variables. The study indicates that FDI inflows have a positive and significant relationship with economic growth in the long-run and short run. If FDI inflows increase, GDP growth will increase. But for exports, it has a negative and significant relationship with economic growth in the long-run.

However, Carkovic and Levine (2002) confirmed that FDI has a negative impact on the growth of the receiving countries by using cross-country data from 1960 to 1995 and applying a generalized method technique for estimations. Their results were not consistent with the theory, that FDI has a positive impact on the economies of the receiving countries. A study by Durham (2004), FDI also has an insignificant and negative impact on the economic growth of the developing countries. He concluded that the flow of FDI depends on the technology absorption capacity of the recipient countries. On the other hand, Ray (2005) argues that FDI does not have positive influence; hence MNCs can be thriving and growing in host country while the domestic companies are remaining not rising. And according to Saqib et al. (2013) had examined the relationship between FDI and economic growth in Pakistan they find that the economic growth in Pakistan is negatively influenced by foreign investment as the domestic investment has given benefits to its economy.

Gu et al., (2008) examined the impact of FDI on China's export performance using the evidence from disaggregated sectors for the period of 1995 to 2005. The found that FDI inflows has a positive and significant effects on Chinese exports. Some studies, such as Lee (2007), Kutan and Vuksic (2007), Prasanna (2010), Njong and Tichakount'e (2011), Achandi (2011) and Haq (2012) also found evidence that FDI has a positive impact export performance of a recipient economy.

Sultan (2013) employed the Vector Error Correction Model to investigate the relationship between FDI inflows and exports from 1980 to 2010 in the case of India. The study found FDI and exports to have a stable long run relationship. On the other hand, Goldberg and Klein (1998, 1999), Sharma (2000), and Nguyen et al., (2012) disagreed and argued that FDI has no impact on export growth

While reviewing previous studies in the literature, it can be understood that there are several different studies that focus on the impact of FDI on exports. In addition to this situation, it is also identified that many different methodologies are considered in these studies, such as regression, vector error correction, Autoregressive Distributed Lag, and generalized method of moment and so on. However, it is determined that there is a few study that considers the leading the impact of FDI on export for Jordan. Therefore, a new study which covers this country will be very beneficial to the literature.

\section{METHODOLOGY AND DATA}

We use annual data for the period of 1980-2018 for empirical analysis. The data series included exports of goods and services as percentage of the GDP (EXP), Net foreign direct investment inflows as percentage of the GDP (FDI), Real exchange rate (REER) and Growth in gross fixed capital formation (K). All data set have been taken from the World Development Indicators of the World Bank, United Nations Conference on Trade and Development (UNCTAD), Jordanian Department of Statistics and Jordan Central Bank. In empirical estimations, all the variables were used in logarithmic form. Figure 1 below shows the time profile of the EXP and FDI, all in the natural logarithm levels over the period 1992-2015. 
FDI

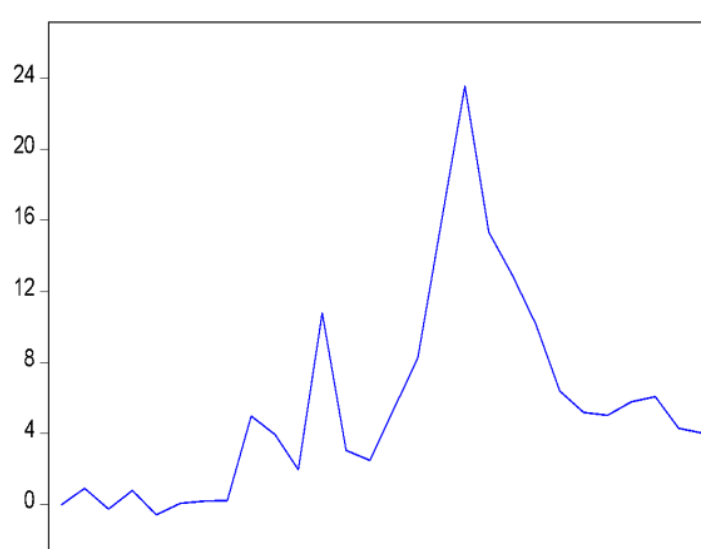

EXP

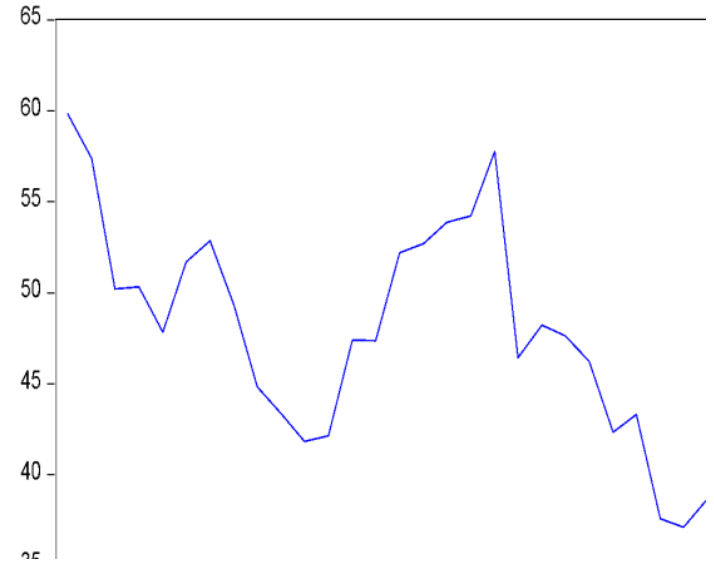

Figure 1. Time profile of the variables (in logarithmic form)

Figure 1 shows that both foreign direct investment and exports increased during the study period. It was found that during the period 1990 and 2000 the increase and change was slow and simple. The researcher finds that the change is consistent for both variables during this period, after 2000 Jordan followed the privatization approach and Jordan's opening of the free trade agreement led to a significant increase in both export volume and FDI. Both variables were reduced by the 2008 financial crisis, but FDI was more affected and responsive than exports for the period after 2008 Due to the consequences of the global financial crisis and Arab Spring.

In this study, to illustrate the impact of foreign direct investment on exports in Jordan, the standard model was formulated based on the traditional economic theory and previous studies. The linear economic model was used. Since the impact of FDI requires a long time to show its impact on host economies, attention was paid to the long-term relationship of variables, so the standard model was based on the results of the diagnostic tests as follows:

$$
\mathrm{EXP}_{\mathrm{t}}=\alpha+\beta \mathrm{FDI}_{\mathrm{t}}+\gamma \mathrm{REER}_{\mathrm{t}}+\varphi \mathrm{K}_{\mathrm{t}}+\varepsilon_{t}
$$

Where:

EXP - Exports of goods and services (\% of GDP).

FDI - Net FDI inflows ( $\%$ of GDP).

REER - Real exchange rate.

$\mathrm{K}-$ Growth in gross fixed capital formation (\% annual).

$\alpha, \beta, \gamma, \varphi$ - Parameters of the model.

$\varepsilon$ - random error.

$\mathrm{t}$-Time period.

For the empirical analysis first, we check non-stationary characteristics of the variables. For this purpose the Augmented Dickey Fuller unit root test (Dickey and Fuller 1981, ADF hereafter) is used. We do not discuss the ADF test here since it is widely used ones in empirical analyses and quite well-known to researchers. Interested readers can find descriptions and discussions of the tests in Dickey and Fuller (1981).

Second, if the orders of integration of the variables are the same, then we will apply cointegration tes(s) to see whether they are cointegrated. To analyze the long-run relationship, we will use the single equation- 
based cointegration method, which is Autoregressive Distributed Lags Bounds Testing approach (ARDLBT hereafter) developed by Pesaran and Shin (1999) and Pesaran et al. (2001) as it outperforms all the alternative cointegration methods in small samples. Therefore, we will use the ARDL estimation results for discussion purposes in the next section.

\section{EMPIRICAL RESULTS AND DISCUSSION}

As a starting point, first we test the variables for a unit root. For this purpose, we use the Augmented Dickey Fuller (ADF) unit root test (Dickey and Fuller, 1981). The results of the unit root test are presented in Table 1.We find that the variables are non-stationary at their levels but they are stationary at first difference, being integrated of order one, I(1). This implies that our variables are non-stationary in levels but stationary in their first differences. In other words, they follow the integration of order one, I(1), processes. Our conclusion that the variables are $\mathrm{I}(1)$ allows us to proceed to the cointegration test.

Table 1

Results of ADF unit root test

\begin{tabular}{|c|c|c|c|}
\hline \multirow[t]{2}{*}{ Variable } & $\begin{array}{l}\text { Panel A: } \\
\text { Level }\end{array}$ & $\begin{array}{c}\text { Panel B: } \\
\text { 1st difference }\end{array}$ & Result \\
\hline & Actual value & Actual value & \\
\hline EXP & -2.0739 & $-5.1497 * * *$ & $\dot{\mathrm{I}}(1)$ \\
\hline FDI & -2.0499 & $-6.3462^{* * *}$ & $\mathrm{I}(1)$ \\
\hline REER & -3.9452 & $-4.6947 * * *$ & $\dot{\mathrm{I}}(1)$ \\
\hline K & -1.9760 & $-7.1871 * * *$ & $\mathrm{I}(1)$ \\
\hline
\end{tabular}

Notes: Maximum lag order is set to two and optimal lag order $(\mathrm{k})$ is selected based on Schwarz criterion in the $\mathrm{ADF}$ test; *,* and *** accordingly indicates rejection of null hypothesis at $10 \%, 5 \%$ and $1 \%$ significance levels; critical values are taken from the table prepared by MacKinnonun (1996). Time period: 1980-2018.

As a next step, we test the variables for long-run co-movement. For this purpose, we employ Pesaran's (Pesaran et al., 2001) Bounds test. The cointegration tests conclude the existence of cointegration relationship among the variables. In other words, the variables move together in the long-run. Since the variables showed a common integration, this indicates a long-term equilibrium relationship between these variables, therefore ARDL model was then used to estimate the long-term relationship and the results were as follows.

Table 2 shows the estimated parameters of the independent and long-term variables. Through the above model we observe the following:

We find a positive and statistically significant effect from FDI to export 5\% level. The results indicate that a $1 \%$ increase in FDI results in $0.13 \%$ increases in exports. This result is consistent with the logic of the economic theory and the reality of the Jordanian economy during the period of study which indicates that exports are developing and growing in the same direction as foreign direct investment. Because foreign companies invest not only to supply the local market but also to supply foreign market, especially Arab Gulf market. The results of this study are consistent with many previous studies, such as Zakia and Ziad (2007), Lee (2007), Kutan and Vuksic (2007), Gu et al. (2008), Prasanna (2010), Njong and Tichakount'e (2011), Achandi (2011) and Haq (2012), Selim et al. (2016). The study of Selim et al. (2016) showed that there is a positive effect of foreign investment on exports in the eastern Balkan countries on exports and the study of Zakia and Ziad (2007) showed the positive effect of direct foreign investment on exports Jordan. 
The ARDLBT estimation and test results

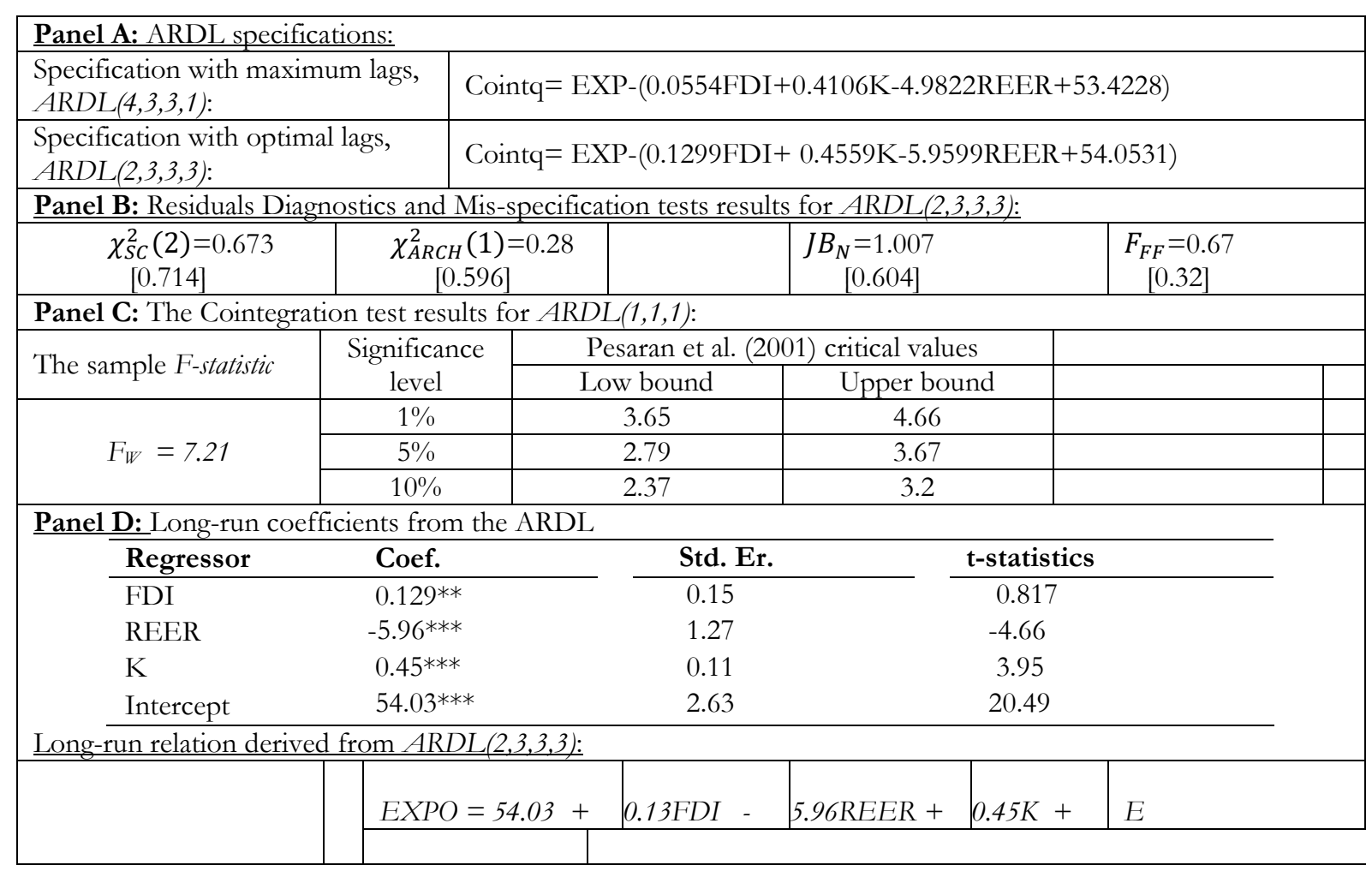

Notes: Coef. and Std. Er. denote coefficient and standard error; *, ** and *** indicate significance levels at 10\%, $5 \%$ and $1 \% ; \chi_{S C}^{2}, \chi_{A R C H}^{2}$ and $\chi_{H E T R}^{2}$ denote Chi-squared statistics to test the null hypotheses of no serial correlation, no autoregressive conditioned heteroscedasticity, and no heteroscedasticity in the residuals; $J B_{N}$ and $F_{F F}$ indicate Jarque-Bera and F-statistic to test the null hypotheses of normal distribution and no functional misspecification respectively; The value of $F_{W}=7.211691$ is greater than bound i1 and thus negates the null hypothesis (the absence of a long-term integrative correlation between the variables) and a long-term common integration. Estimation period: 1980-2018.

For the real exchange rate coefficient, we note that is negative. If the real exchange rate increases (appreciation of the national currency in the case of Jordan) by a 1\%, the exports will fall by $5.96 \%$, with the stability of other factors. This result is appropriate with the economic theory. According to the theory, the appreciation of the national currency caused a decrease in exports as domestic commodities made them more expensive in comparison with foreign commodities.

We also found that, the impact of gross capital formation on exports is a positive and statistically significant at the $1 \%$ level. Other things held constant, a $1 \%$ increase in gross capital formation increases export by $0.45 \%$.

The study was characterized by the use of a modern methodology and a longer period of time for the relationship between the variables of the study and use of several diagnostic tests to ensure the integrity of the study model of statistical problems. 


\section{CONCLUSION}

The main objective of this study was to investigate the impact of foreign direct investment on exports in Jordan in the period 1980 to 2018 and concluded as follow:

There is a long-term common integrative relationship between the independent variables (FDI, K, REER) and the dependent variable (EXP).

There is a positive and statistically significant relationship between FDI and export in the case of Jordan This implies that a 1\% increase in FDI results in $0.13 \%$ increases in Export with the stability of the impact of other factor.

There is a positive and statistically significant relationship between the gross capital formation $(K)$ exports (EXP).

There is a negative and statistically significant relationship between Real Exchange Rate (REER) and exports.). All other things being equal, a 1\% increase in real exchange rate (appreciation of national currency) decrease exports by $5.96 \%$.

The results show that the adjusted-R square (adj- R2) was $84.2 \%$. This means the independent variables combined explain $84.2 \%$ of the change in the proportion of exports of GDP.

Depending on the results of the study, some recommendations can be identified, including:

Enhancing and developing the investment environment and strengthening Jordan's position as a major attraction for foreign investments at the regional and global levels through: expanding and diversifying the production base, facilitating the registration and licensing of investment projects, activating the trade movement and opening new export markets for local industries, and providing some incentives for the foreign investments; such as solar power to reduce production costs, free some taxes and grant grace periods.

The Jordanian government should take further promotional, marketing and advertising measures to present the climate, benefits and investment incentives available in Jordan, and work to modernize and develop investment promotion laws to increase its competitiveness in attracting export-oriented investments, in additional to attract the foreign investments that rehabilitate local factories and train Jordanian labor on the production of goods that meet the requirements of access to international markets.

\section{ACKNOWLEDGEMENT}

All sources of funding of the study should be disclosed. Please clearly indicate grants that you have received in support of your research work. Clearly state if you received funds for covering the costs to publish in open access.

\section{REFERENCES}

Achandi, E.L. (2011). Effect of foreign direct investments on export performance in Uganda. Makerere University, Uganda.

Adelman, I., \& Chenery, H. (1996). Foreign aid and economic development: the Case of Greece. The Review of Economic and Statistics, 111(1).

Algunacil, M., \& Ort, V. (2002). A Multivariate cointegrated model testing for causuelity between export and outward foreign investment: The Spanish case, Applied Economic, 34, 118- 132.

Almahdi, A. (2003). The globalization of the global economic system and the WTO, Faculty of Commerce. Helwan University, 41-42.

Alsawaei, K., (2014). The effect of foreign investment on total variables in the Jordanian economy. Jordanian Journal of Economic Sciences, 3(1), 62-95. 
Arab Investment Guarantee and Export Credit Corporation.(2015) Arab Investment Climate Report 2015, Sporadic preparation.

Benmamoun, M., \& Lehnert, K. (2013). Financing growth: Comparing the effect of FDI, ODA, and international remittances. Journal of Economic Development, 38(2), 43-65.

Buckley P., Clegg J., \& Wang C. (2002). The impacts of FDI on the performance of Chinese Manufacturing Firms, Journal of International Business Studies, 19(2), 55-67.

Carkovic M., \& Levine, R. (2002). Does foreign direct investment accelerate economic growth?. University of Minnesota, Department of finance, working paper.

Dausa,J..(2007). Malaysian foreign direct investment and growth. Journal of Economic Cooperation, 28(2), 83-99.

Dickey, D., \& Fuller,W. (1981). Likelihood Ratio Statistics for Autoregressive Time Series with a Unit Root. Econometrica, 49, 1057-1072.

Durham, J. B. (2004). Absorptive capacity and the effects of foreign direct investment and equity foreign portfolio investment on economic growth. European Economic Review, 48(2), 285-306.

Dutt, A. (1998). Globalization, FDI and Southern Growth, Economic Effects of Globalization. 46-96. In Chen, J.R. Eoconomic Effect of Globalization, Avebury

Economic and Social Council of Jordan (2012), The Economic and Social Report for the year 2012.

Gu, W., Awokuse, T.O. \& Yuan, Y. (2008). The Contribution of Foreign Direct Investment to China's export performance: Evidence from disaggregated sectors, 2008 Annual Meeting, July 27-29, 2008, Orlando, Florida 6453.

Golberg, S., \& Klein, W. (1998). Foreign Direct - Investment, Trade and Real Exchange Rate Linkages in Developing Countries, in Reuben Glick (Ed) Managing capital flows and Exchange Rates: Lessons from the pacific Basin. Cambridge University Press. 5th Edition.

Haq, G. (2012). Impact of foreign direct investment on exports - a case study of Pakistan. Sarbad University of Science and Information Technology, University Town Peshawar, Pakistan

Jaumatte, F. (2004). Foreign direct investment and regional trade agreement: The market size effect revisited. International Monetary Fund, IMF WP/04/206.

Khader, H., (2004). Foreign direct investment - definition and issues. Arab Planning Institute, Kuwait, Development Bridge, Third Year, 32, 2-28.

Kindleberger, C. (1969). The theory of direct investment and the international corporation. American Business Abroad, MA: MIT Press.

Kutan, A.M. \& Vuksic, G. (2007). Foreign direct investment and export performance: Empirical evidence. Comparative Economic Studies, 49 (3), 430-445

Lee, S.W. (2007). Foreign direct investment and export performance: The case of Taiwan. M. Econ - Res. Thesis, Economics and Information System, University of Wollongong, Australia.

Marino, A. (2000). The impact of FDI on developing countries growth: Trade policy matters. ISTAT National Institute of Statistics, Italy.

Mousawi, W., (2015). The dynamic interaction between foreign direct investment, economic growth, exports and the dinar exchange rate in Algeria. Journal of Economic Sciences, 2(2), 115-128.

Nair-Reichert, U. \& Weinhold, D. (2001). Causality tests for Cross Country Panels: a new look at FDI and Economic Growth in Developing Countries. Oxford Bulletin of Economic and Statistics, 63(2), 153-171.

Nguyen, D.B, Tu, T.A \& Chu, T.M.P (2012). On the linkage between FDI and TRADE: Evidence from Vietnam, SECO/WTI Academic Corporation Project, Working Paper Series 5/2012.

Njong, A.M. \& Tchakount'e, R. (2011). Investigating the effects of foreign direct investment on export growth in Cameroon. Faculty of Economics and Management, University of Dschang, Cameroon. 
Olayiwoaand, k. \& Okodua, H. (2013). FDI, non-oil exports and economic growth in Nigeria: A causal analysis. Asian Economic and Financial Review, 3(11), 1479-1496.

Omar, Dunia, (2007). The impact of exports on the flow of foreign direct investment in selected Arab countries. Rafidain Development Journal, 68(29), 129-146.

Palma, G. (1978). Dependency, a formal theory of underdevelopment or mythology for the analysis of concerte situations of under development?. Word Development, 6(2), 881-924.

Pesaran M, Shin Y (1999) An autoregressive distributed lag modeling approach to cointegration analysis in S. Strom, (ed) Econometrics and Economic Theory in the 20 th Century: The Ragnar Frisch centennial Symposium, Cambridge University Press, Cambridge.

Pesaran, M. \& Shin, Y., \& Smith, R. (2001). Bounds testing approaches to the analysis of level relationships. Journal of Applied Econometrics, 16(8), 289-326.

Prasanna, N. (2010). Impact of foreign direct investment on export performance in India. Journal of Social Sciences, 24(1), 65-71.

Ray, P.K. (2005). FDI and industrial organization in developing countries: The challenge of globalization in India. Ashgate cop.

Salvatore, Dominick. (2001). International economics. Seventh Edition. John Wiley and Sons, 399.

Saqeb, N., Masnoon, M., \& Rafique, N. (2013). Impact of foreign direct investment on economic growth of Pakistan. Advances in Management \& Applied Economics Economics, 3(1), 35-45.

Selim,N. and Reci,K. \& Sadiku, L. (2016). The impact of FDI on the export performance: Empirical evidence for Western Balkan countries. ILIRIA International Review, 1(1), 57-66.

Sharma, K. (2000). Export growth in India: Has FDI played a role. Yale University Economic Growth Center Discussion Paper, No. 816. Available online at: http://www.econ.yale.edu/ egcenter/EGCdp3.htm

Sultan, Z.A. (2013), A Causality Relationship between FDI inflows and Export: The Case of India, Department of Management, College of Business Administration, Salman Bin Abdulaziz University Alkharj, Kingdom of Saudi Arabia.

Sunkel, O. (1969). National development policy and external dependence in Latin America, The Journal of Development Studies, 6(1).

Sultanzzaman, Md. R., Fan, H., \& Wang, B. (2018). The role of FDI inflows and export on economic growth in Sri Lanka: An ARDL. Approach, Cogent Economics and Finance, 6(1).

Todaro, M., \& Smith, S. (2015). Economic Development. Eleventh Edition, PEARSON, Boston.

UNCTAD, World Investment Report, 2003-2005.

UNCTAD. (2010). World investment report, FDI from developing and transition economics: Implications for development, U.N, New York. http://www.unctad.org/en/docs/wir2010 en.pdf.

UNCTAD. (2015). World investment report, FDI from developing and transition economics: Implications for development, U.N, New York. http://www.unctad.org/en/docs/wir2010 en.pdf.

United Nations (2005). Transnational Corporations and the Internationalization of ReD. World Investment Report 2005, UNCTAD, United Nations New York and Geneva.

Vincent, F., (2008). Dependency theory: An introduction, in the development economics reader, ed. Giorgio Secondi, 58-64.

Zakia, M., \& Ziad, A. (2007). The Impact of foreign direct investment and imports on economic growth: The Case of Jordan. Journal of Economic and Administrative Sciences, 23(1), 1-31. 